\title{
The Challenge of Implementing the European Network of Protected Areas Natura 2000
}

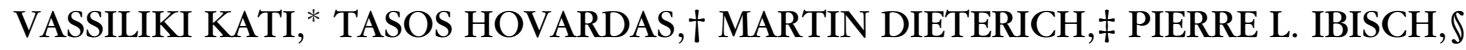 \\ BARBARA MIHOK, ${ }^{* *}$ AND NURIA SELVA $\dagger$
}

*University of Patras, Department of Environmental \& Natural Resources Management, Seferi 2, 30100 Agrinio, Greece, emailvvati@upatras.gr; vkati@cc.uoi.gr

†University of Cyprus, 75 Kallipoleos Street, Nicosia 1678, Cyprus

‡Universität Hohenheim, Institut für Landschafts- und Pflanzenökologie, August-von-Hartmannstrasse 3, 70599 Stuttgart, Germany §Eberswalde University for Sustainable Development, Centre for Econics and Ecosystem Management, Alfred-Moeller-Str. 1, 16225 Eberswalde, Germany

**Hungarian Academy of Sciences, Centre for Ecological Research, MTA ÖK Lendület Ecosystem Services Research Group, H-2163 Alkotmány u. 2-4, Vácrátót, Hungary; Society for Conservation Biology - Europe Section

††Polish Academy of Sciences, Institute of Nature Conservation, Mickiewicza 33, 31-120 Krakow, Poland

\begin{abstract}
Established under the European Union (EU) Birds and Habitats Directives, Natura 2000 is one of the largest international networks of protected areas. With the spatial designation of sites by the EU member states almost finalized, the biggest challenge still lying abead is the appropriate management of the sites. To evaluate the cross-scale functioning of Natura 2000 implementation, we analyzed 242 questionnaires completed by conservation scientists involved in the implementation of Natura 2000 in 24 EU member states. Respondents identified 7 key drivers of the quality of Natura 2000 implementation. Ordered in decreasing evaluation score, these drivers included: network design, use of external resources, legal frame, scientific input, procedural frame, social input, and national or local policy. Overall, conservation scientists were moderately satisfied with the implementation of Natura 2000. Tree modeling revealed that poor application of results of environmental impact assessments (EIA) was considered a major constraint. The main strengths of the network included the substantial increase of scientific knowledge of the sites, the contribution of nongovernmental organizations, the adequate network design in terms of area and representativeness, and the adequacy of the EU legal frame. The main weaknesses of Natura 2000 were the lack of political will from local and national governments toward effective implementation; the negative attitude of local stakebolders; the lack of background knowledge of local stakeholders, which prevented well-informed policy decisions; and the understaffing of Natura 2000 management autborities. Top suggestions to improve Natura 2000 implementation were increase public awareness, provide environmental education to local communities, involve bigh-quality conservation experts, strengthen quality control of EIA studies, and establish a specific Natura 2000 fund.
\end{abstract}

Keywords: conservation biologists, European Directives, governance, protected area management, questionnaire, transnational conservation

El Reto de Implementar la Red Europea de Áreas Protegidas Natura 2000 Kati et al. 13-590

Resumen: Establecida bajo las Directivas de Aves y Hábitats de la Unión Europea (UE), Natura 2000 es una de las redes internacionales de áreas protegidas más grande. Con la designación espacial de sitios por los miembros de la UE casi finalizada, todavía queda por vencer el obstáculo más grande: el manejo apropiado de los sitios. Para evaluar el funcionamiento trans-escala de la implementación de Natura 2000, analizamos 242 cuestionarios completados por científicos de la conservación involucrados en la implementación de Natura 2000 en 24 estados miembros de la UE. Los encuestados identificaron siete conductores clave de la calidad de la implementación de Natura 2000. Ordenados por efecto decreciente, estos conductores incluyeron: diseño de red, uso de recursos externos, marco legal, aporte científico, marco de procedimiento, aportación social y políticas nacionales o locales. En general, los científicos de la conservación estuvieron moderadamente 
satisfechos con la implementación de Natura 2000. El modelado de árbol reveló que la mala aplicación de los resultados de evaluaciones de impacto ambiental fue considerado una gran limitación. Las principales fuerzas de la red incluyeron el incremento sustancial del conocimiento científico de los sitios, la contribución de organizaciones no gubernamentales, el diseño adecuado de la red en términos de área y representatividad y la adecuación del marco legal de la UE. Las principales debilidades de Natura 2000 fueron la carencia de voluntad política de los gobiernos locales y nacionales para una implementación efectiva, la actitud negativa de los accionistas locales, la falta de conocimiento de trasfondo de los accionistas locales, la cual impidió decisiones políticas bien informadas y la falta de personal entre las autoridades de manejo de Natura 2000. Las sugerencias para mejorar la implementación de Natura 2000, en orden descendente, fueron: incrementar el conocimiento del público, proporcionar educación ambiental a las comunidades locales, involucrar a expertos en la conservación de alta calidad, fortificar el control de calidad de los estudios de evaluación de impacto ambiental y establecer un fondo económico específico para Natura 2000.

Palabras Clave: biólogos de la conservación, conservación trasnacional, cuestionario, Directivas Europeas, gobernación, manejo de áreas protegidas

\section{Introduction}

Worldwide it is recognized that protected areas form a cornerstone of efforts to conserve nature and biodiversity (Chape et al. 2008). In line with the provisions of the convention on biological diversity, the European Union (EU) has gradually established a system of protected areas forming a transnational and coherent network, under the name Natura 2000 that targets the conservation of the EU natural heritage. The terrestrial component of Natura 2000 covers $17.9 \%$ of EU-27 land territory, encompassing 25,717 terrestrial sites $\left(767,995 \mathrm{~km}^{2}\right)$. The marine component of the Natura 2000 network is still under development (EC 2013b). Natura 2000 comprises sites of community importance for the conservation of natural habitats, wild flora and fauna (designated according to the provisions of the Habitats Directive), and special protection areas dedicated to the conservation of birds (designated according to the provisions of the Birds Directive). Designation of Natura 2000 sites aims to achieve continued protection of habitats and species of EU conservation interest.

A suite of legal, policy, and financial instruments are currently provided by the EU to facilitate Natura 2000 management, following standardized procedures in accordance with the EU Birds and Habitats Directives. These EU conservation directives have to be implemented through national conservation law. Failure by EU member states to achieve tasks may activate a centralized infringement procedure launched by the EU administration. A comprehensive EU policy framework for biodiversity conservation has been presented by the EU biodiversity action plan and the EU 2020 biodiversity strategy (EC 2006, 2011a). While the main responsibility for financing the Natura 2000 network (estimated $€ 5.8$ billion/year) lies with each member state, the EU has developed cofinancing opportunities so as to integrate nature conservation into key EU policies. The portfolio of cofunding instruments lies mainly in the ecological component of the Common Agricultural Policy and pro- vides possibilities for cofinancing of national programs to support farmers and landowners in properly managing Natura 2000 sites. In addition, the Life + program provides funds for best practices, and, to a lesser extent, funds are provided through the European Maritime and Fisheries Fund and the EU Research Framework Program (EC 2011b).

Worldwide, protected areas are deemed not only as biological diversity reservoirs, but also as nodes of green infrastructure that provide environmental resilience and ecosystem services; thus, protected areas contribute to human well-being and wealth on local, national, and global scales (Bastian 2013; EC 2013a; Doak et al. 2014). In spite of these benefits, the designation and management of protected areas does not always proceed without conflict. Public support, and in particular the approval and participatory role of local stakeholders, has been envisaged as crucial for the long-term success of protected area management (Dudley et al. 2005; Chape et al. 2008).

The Natura 2000 experiment, EU member states working together toward a common conservation target regardless of political boundaries, is considered a visionary and cooperation-generating project. In spite of this, the current conservation status of Europe's biodiversity may be characterized as unsatisfactory: large EU ecological footprint vis-à-vis its bio-capacity (EEA 2011a), high fragmentation rate of European territory (EEA 2011b), large proportion (83\%) of EU-protected habitat and species under a nonfavorable or unknown conservation status (EEA 2010a), and failure of the EU to meet its 2010 goal to halt biodiversity loss. Despite the great ecological, scientific, social, economic, and political significance of Natura 2000, studies on its effectiveness remain local and fragmented (Nolte et al. 2010) or are restricted to selected biological groups (Donald et al. 2007). Our survey targeting European conservation scientists with a structured questionnaire is the first poll-based attempt to evaluate the cross-scale functioning of the different facets of Natura 2000 implementation. We sought to assess the key drivers in the implementation of Natura 2000; 
pinpoint the main strengths and weaknesses of the current Natura 2000 implementation; explore differences among conservation scientists' perceptions and opinions; and summarize a set of top suggestions to improve Natura 2000 implementation. Our results are relevant for EU and national conservation policies and provide insights for greater effectiveness in the management of reserve networks worldwide.

\section{Methods}

\section{Data Collection}

We developed a questionnaire with 56 items divided among 3 sections (Supporting Information), after testing its validity and reliability through a pilot survey (32 respondents) (Field 2003). The first section concerned the respondent's profile. In the second section, respondents rated 30 items corresponding to various aspects of Natura 2000 implementation on a 5-point Likert scale. In the third section, they were asked to choose the top 5 (from a list of 20) suggestions for improving Natura 2000 effectiveness or to provide their own suggestions in free text form. The anonymous survey was presented to the community of conservation scientists during the 2 nd European Congress for Conservation Biology in September 2009 and was widely distributed via the professional network of the Society for Conservation Biology Europe Section.

\section{Data Analyses}

We first conducted a factor analysis to assess the validity of our questionnaire. We then assessed questionnaire reliability in terms of Cronbach's alpha index (Cronbach, 1951; Field 2003). We used factor scores to perform a k-means cluster analysis to examine whether the total sample could be segmented in clusters of respondents with different satisfaction levels. We used $\chi^{2}$ tests to explore the influence of profile characteristics on their level of satisfaction. We used tree modeling to examine which suggestions (independent variable) were characteristic among the different respondent clusters (dependent variable) (Hovardas \& Poirazidis 2006). The classification tree produced is a collection of a series of rules, which are determined by recursive partitioning and are of the form if suggestion $X$ is selected and if suggestion $Y$ is also selected, then respondents who made these selections are most likely to belong to cluster $Z$. Chi-square automatic interaction detection was used; at each step, the independent variable that had the strongest interaction with the dependent variable was chosen. We used only the predefined suggestion list in the analysis (free form suggestions accounted for $<1 \%$ of the sample). All analyses were performed using SPSS software (version 20).

\section{Results}

\section{Profile of Respondents}

The survey respondents were quite diverse, consisting of 242 conservation professionals (Supporting Information) with a strong academic background from $24 \mathrm{EU}$ countries. Fifty-six percent of respondents were under 40 years old. Respondents were employed in different sectors, and 70\% were involved in several Natura 2000 implementation stages (Table 1).

Table 1. Profile of the 242 respondents taking part in the Natura 2000 survey.

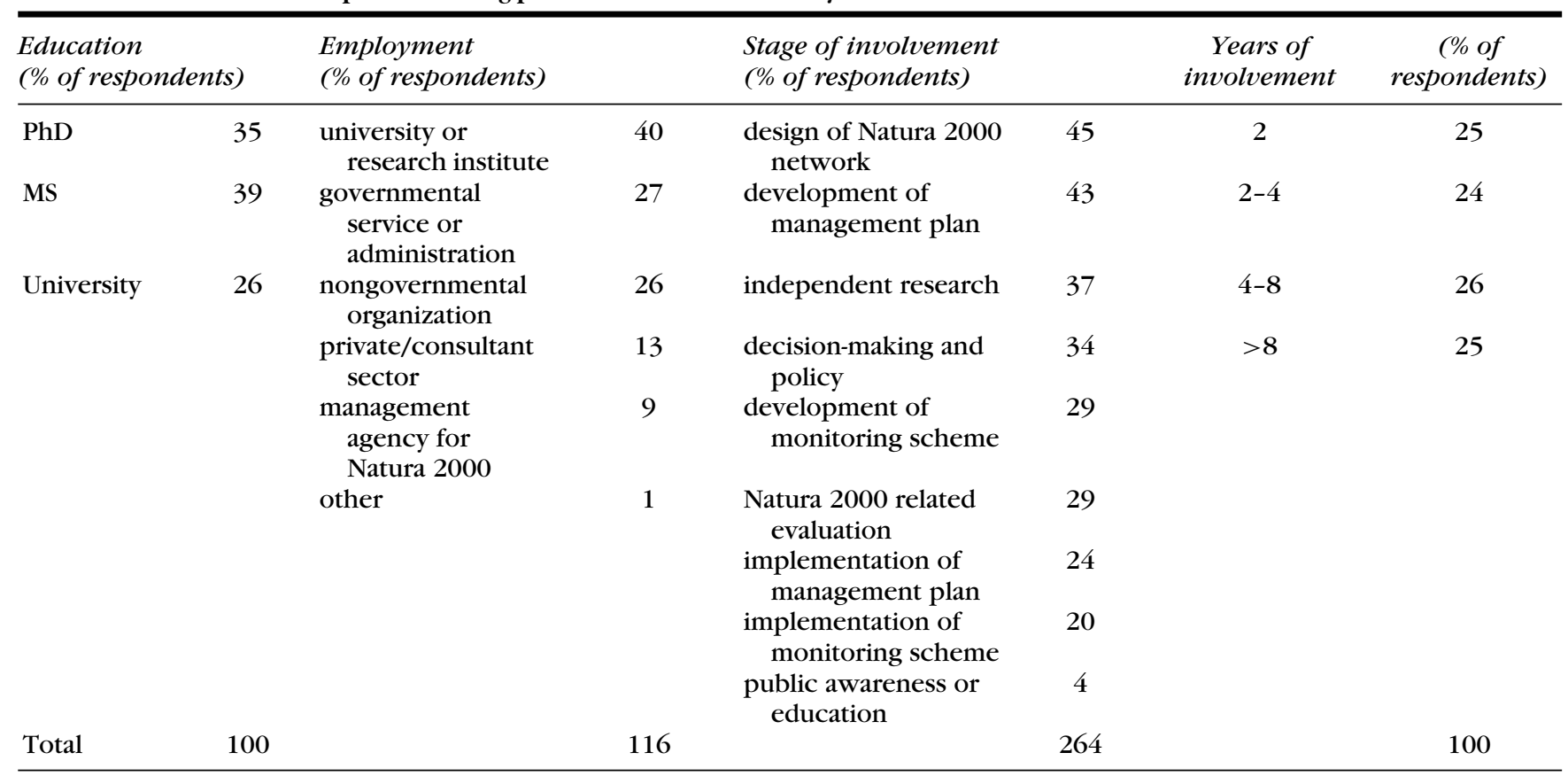


Table 2. Average item scores, factor analysis of questionnaire items, and Cronbach's alpha values for factors in a survey of conservational professionals in Europe about Natura 2000 (Supporting Information).

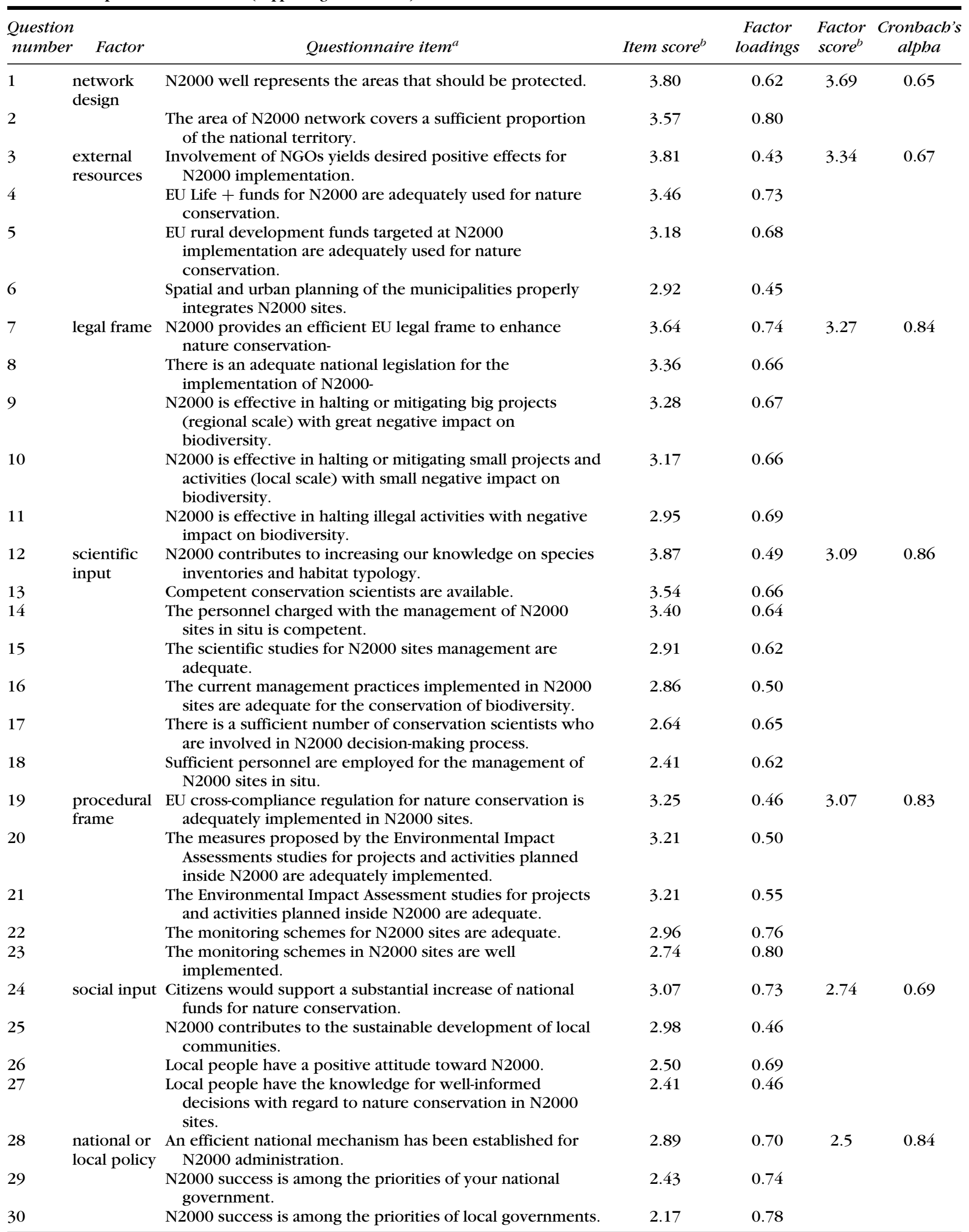

abbreviation: N2000, Natura 2000.

${ }^{b}$ Average score on a scale from 1 (not at all) to 5 (very much). 
Table 3. Suggestions of survey respondents on how to improve Natura 2000 implementation (up to 5 suggestions could be selected from a list of 20).

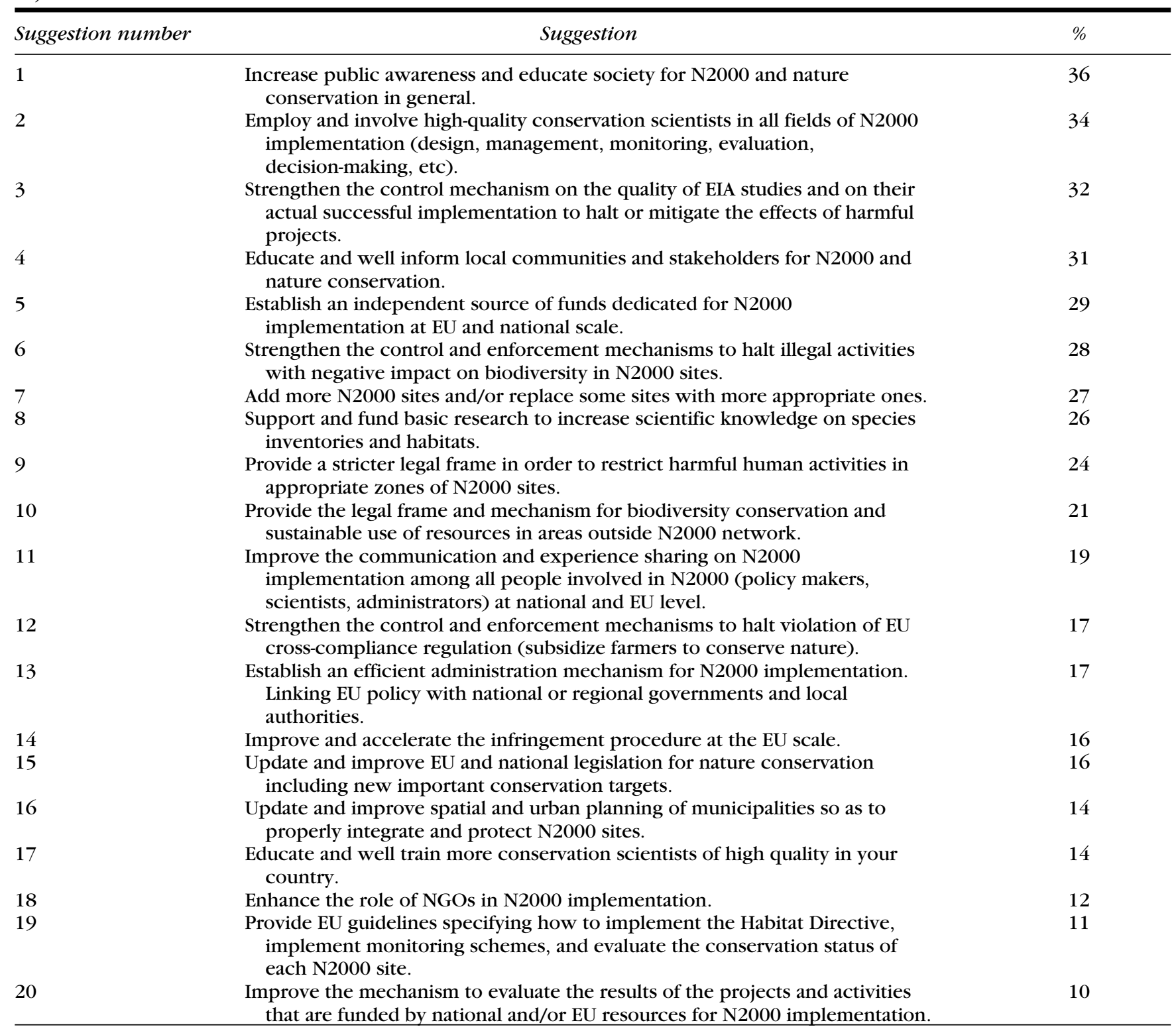

\section{Natura 2000 Implementation}

The questionnaire presented good reliability and validity and had 7 distinct and coherent factors (factor loadings: 0.43-0.80, Cronbach's alpha $\geq 0.65$ ). Overall, conservation scientists expressed a moderate satisfaction regarding the implementation of Natura 2000 (mean score 3.07). The top 5 items that contributed to Natura 2000 strengths were the increase of biodiversity knowledge in Europe, the positive involvement of nongovernmental organizations (NGOs), the adequate network designation in terms of area and representativeness, and the adequate associated legal frame in EU for nature conservation
(Table 2). Policy and social input factors scored low. The political unwillingness at local and national levels for Natura 2000 implementation, the negative attitude of local people toward Natura 2000, the lack of knowledge of local stakeholders regarding Natura 2000, and the lack of employees for Natura 2000 site management (scientific input factor) were identified as the main weaknesses. The top suggestions for improved Natura 2000 implementation were in line with the weaknesses identified, but also included other important items, such as the improvement of environmental impact assessment (EIA) and the establishment of a distinct and independent fund for the network management (Table 3). 
Table 4. Results of k-means cluster analysis of survey respondents according to scores of factors ${ }^{\mathrm{a}}$ associated with Natura 2000 implementation.

\begin{tabular}{|c|c|c|c|c|}
\hline Factor & Satisfied (20\%) & Moderately satisfied (48\%) & Not satisfied (32\%) & $F^{b}$ \\
\hline Network design & 4.18 & 3.74 & 3.11 & 32.78 \\
\hline External resources & 4.19 & 3.37 & 2.64 & 73.40 \\
\hline National/local policy & 3.72 & 2.35 & 1.43 & 138.91 \\
\hline Procedural frame & 4.13 & 3.16 & 2.06 & 149.89 \\
\hline Scientific input & 4.03 & 3.14 & 2.31 & 130.67 \\
\hline
\end{tabular}

${ }^{a}$ Average score on a scale from 1 (not at all) to 5 (very much).

${ }^{b}$ All significant at $p<0.0001$.

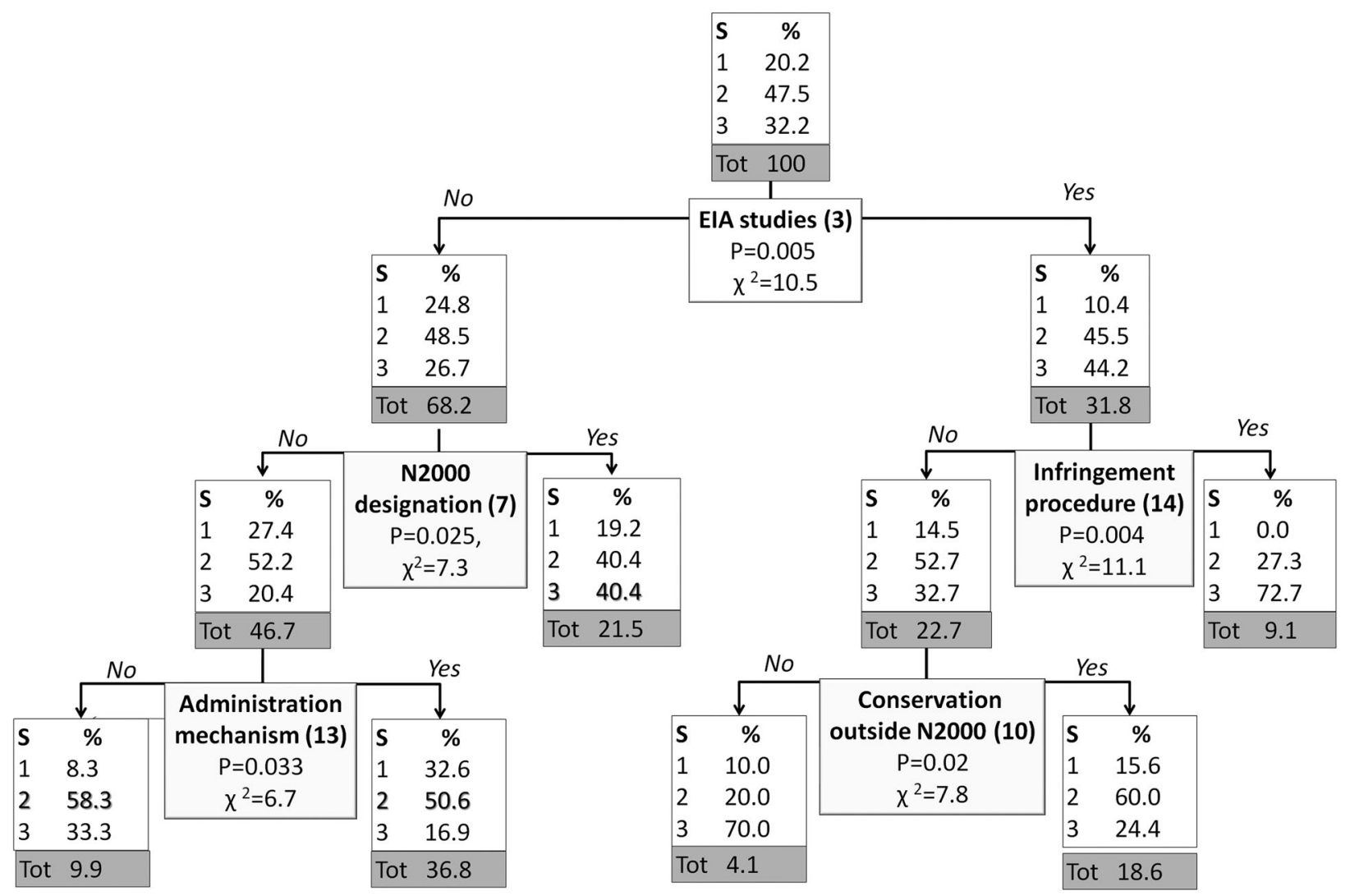

Figure 1. Results of tree modeling of respondents' degree of satisfaction with Natura 2000 implementation according to their suggestions (S, satisfaction group [1, satisfied; 2, moderately satisfied; 3, not satisfied]; \%, percentage of respondents assigned to each satisfaction group; Tot, total proportion of respondents in each tree branch; number in parentheses, suggestion rank as in Table 2).

\section{Heterogeneity of Opinion among Respondents}

Results of the k-means cluster analysis classified respondents in 3 groups according to their factor scores: satisfied (20\%), moderately satisfied (48\%), and not satisfied (32\%) (Table 4). All 7 factors contributed significantly to the segregation of respondents into groups. Those respondents who had significantly greater probability of being in the not-satisfied group were older respondents (age range was from $<40$ to $>50$ years old) $\left(\chi^{2}=14.11\right.$; $p<0.01)$; had greater experience in Natura 2000 implementation in terms of years of involvement $\left(\chi^{2}=13.19\right.$; $p<0.05)$; had worked for an NGO $\left(\chi^{2}=8.80 ; p<0.05\right)$ or for the government $\left(\chi^{2}=10.76 ; p<0.01\right)$; and had been involved in decision making and policy $\left(\chi^{2}=8.65\right.$; $p<0.05)$ or in the development of Natura 2000 management plans $\left(\chi^{2}=9.42 ; p<0.01\right)$. Respondents who had been involved longer in Natura 2000 were more likely to be engaged in the policy field $\left(\chi^{2}=40.02 ; p<0.001\right)$. Factor scores did not differ significantly between respondents employed by universities or research institutions and those employed in other sectors (Mann-Whitney tests, 
$p>0.05$ ). Tree modeling initially split respondents on the basis of their suggesting or not suggesting the strengthening of the mechanisms controlling environmental impact assessments (EIA) (Fig. 1). Specifically, those respondents who highlighted the need for improved quality of EIA and the need to improve and accelerate the infringement procedure at the EU scale (i.e., a procedure to determine whether a member state has fulfilled its obligations under EU law) had a high probability of belonging to the notsatisfied group. If respondents suggested strengthening of EIA but did not mention infringement procedure, they most likely belonged to the moderately satisfied or the not satisfied groups; differentiation between not satisfied being associated with not considering the need to enhance conservation in areas outside the Natura 2000 network. A critical mass of moderate respondents was allocated to the left branch of the tree on the basis of their not selecting "strengthening the quality control of EIA" and not selecting "add more Natura 2000 sites or replace some sites with more appropriate ones."

\section{Discussion}

Ours is the first European poll-based study to target exclusively conservation experts so as to examine their opinions on the successes and failures of one of the largest networks of protected areas worldwide. Overall, scientists expressed moderate satisfaction regarding the implementation of Natura 2000 in the EU. Although the survey was completed in February 2010, we consider that the respondents' satisfaction level reflects the current state of the situation because the basic legal, policy, procedural, and financial frames for Natura 2000 implementation have remained relatively stable since 2010 . Despite some progress reported in establishing management agencies and conservation measures in Natura 2000 sites, as well as in re-assessing the key priorities and the financial needs for Natura 2000 implementation under the Prioritized Action Frameworks (F. Papoulias, personal communication), implementation progress is considered slow in most member states (BirdLife Europe 2012). Respondents identified 7 key factors as the main drivers regulating Natura 2000 implementation: network design, external resources, legal frame, scientific input, procedural frame, social input, and national and local policy.

\section{Network Design}

Spatial designation of the network of protected areas was identified as a strength of Natura 2000, both in terms of sufficient area of national territory covered and its representativeness. This factor scored the highest overall. However, respondents suggested a network update with new or more appropriate sites and stressed the need for better implementation of nature conservation policies outside Natura 2000 (Cai \& Pettenella 2013). The network has substantially increased land cover under protection in the EU (EEA 2012); however, its successful inclusion of sites with the highest biodiversity that also complement the existing reserve network has been assessed positively (Brodier et al. 2013; Schmiedel et al. 2013), rather positively (Gruber et al. 2012), or rather negatively (Dimitrakopoulos et al. 2004; Araújo et al. 2007; Maiorano et al. 2007; Iojâ et al. 2010; Jantke et al. 2011; Bosso et al. 2013; D'Amen et al. 2013). Overall, there are significant concerns over the extent to which the existing Natura 2000 network can guarantee biological diversity persistence at present and in the future due to the lack of consideration of systematic conservation planning and landscape connectivity in the designation process, the small size of many protected areas, undervaluation of invertebrates, and likely impacts of climate change (Gaston et al. 2008; Opermanis et al. 2012; Cabeza 2013; Gillson et al. 2013; Hamann \& Aitken 2013).

\section{External Resources}

The factor of adequate integration of external resources into Natura 2000 implementation was highly valued by respondents, particularly by the satisfied group. They stressed the positive role of environmental NGOs, but few of them suggested that their role should be expanded. NGOs seem to have served as control mechanisms by enhancing Natura 2000 site designation and appropriate implementation (Cent et al. 2013).

Respondents did not have a very positive attitude toward the use of the rural development funds, which are reported to have been used in activities that have harmed priority habitats, such as Spanish heaths (Rego et al. 2013), and recent reform of Common Agricultural Policy seems not to have adequately advanced conservation goals (Pe'er et al. 2014). The use of Life + funds, exclusively devoted to best practice examples for Natura 2000 implementation, was evaluated more positively. However, it was suggested an independent funding mechanism be established that is solely dedicated to Natura 2000 implementation at EU and national scales, so as to fund the endeavor in a more clear-cut and straightforward way. A division of opinion is apparent for the future of Natura 2000 financing, with the overwhelming majority of stakeholders favoring an independent Natura 2000 fund, while member states and the European Commission prefer the current integration of Natura 2000 financing into other relevant European policies (EC 2004, 2011c).

\section{Legal Frame}

The Birds and Habitats Directives were clearly considered one of the main strengths of European conservation policies. In spite of some inherent deficiencies of the directives, such as their inflexibility in updating habitats 
and species listed in their Annexes and the poor representation of some less well-known taxa, they have provided a vigorous and pioneer legislative framework that has allowed very different countries to work together under a common legal frame. The respondents were slightly less positive about the effectiveness of national legal frames to implement Natura 2000. This might reflect inadequate translation of EU provisions into national legislation and the subsequent failure or delay of EU member states to comply with the EU directives, as shown by the numerous infringement cases brought to the European Court of Justice.

Respondents considered Natura 2000 as quite effective at halting or mitigating big development projects with great negative impact on biological diversity but less effective at halting harmful small projects or illegal activities. They emphasized the need to strengthen the control and enforcement mechanisms to halt illegal activities and the need for a stricter legal frame restricting harmful human activities. Recreational activities, pollution, logging, wood harvesting, hunting or killing of animals, and farming or grazing without considering the need for protection of biodiversity are among the most prevalent threats in Natura 2000 sites (Nolte et al. 2010). Human presence is high in the Natura 2000 network, though threats differ between southern and more densely populated western Europe (Tsiafouli et al. 2013; Wamelink et al. 2013). The weakness of Natura 2000 to halt illegal activities is a reality in several EU member states, particularly in those lacking a long history of conservation policy (Iojâ et al. 2010).

\section{Scientific Input}

Respondents ranked the increase of biological knowledge gathered for target species and habitats as the greatest strength of the Natura 2000 designation process. Natura 2000 generated the first systematic European biodiversity database as an asset for future generations. However, respondents suggested that further funding of basic research on biological diversity patterns in Europe and Natura 2000 sites remains of primary importance. Respondents also identified that high-quality conservation scientists were available but noted that personnel currently charged with the management of Natura 2000 were less competent. They clearly stressed the need to employ high-quality conservationists in all Natura 2000 stages as a key point for its success.

\section{Procedural Frame}

Respondents tended to agree that cross-compliance regulations have been implemented adequately at Natura 2000 sites. Such regulations request farmers to comply with certain conservation targets in order to qualify for full-scale subsidies. In contrast, respondents strongly sug- gested that the quality and implementation of EIA be improved so as to improve Natura 2000 implementation. Assessment of EIA quality distinctly split respondents in the tree model. Therefore, it appears that different procedural frames allow varying interpretations of the EIA process in the national guidance documents (Peterson et al. 2010). Deficient biodiversity knowledge, uncertainty in predicting cause-effect relationships, and ambiguity in the science-policy interface imposed by conflicts among stakeholders render implementation of EIA results a difficult process (Opdam et al. 2009). Even if EIAs are performed, the low quality of the assessments has been documented to have led to financial investments with negative impact on the conservation status of habitats and species inside Natura 2000 sites (Söderman 2009; Peterson et al. 2010; Wołoszyn et al. 2012). Respondents underlined that there is a long way ahead to improve the quality of monitoring schemes and their implementation across EU member states. The latter is also evident in the last EU report, which stated that the conservation status of $13 \%$ and $27 \%$ of regional habitats and species, respectively, remains unknown (ETC/BD 2008). Therefore, the procedural frame of Natura 2000 can be improved mainly through the better implementation, design, and funding of biodiversity monitoring schemes and the stricter implementation of EIA control mechanisms.

\section{Social Input}

The social input factor was identified as one of the main weaknesses of Natura 2000. Although respondents thought people were in general sensitive to environmental issues, they noted that local people in particular had a negative attitude and poor knowledge of nature conservation, which hampered Natura 2000 implementation. Therefore, among the suggestions, participants ranked the increase of public awareness by educating society on nature conservation as the number one priority for Natura 2000 success, underlining in particular the need to keep local stakeholders well informed. The general picture depicts environmentally sensitive people, who generally subscribe to improved nature conservation as long as this does not touch their personal behaviors or interests, which indicates some ignorance of the importance of nature conservation (EEA 2010b). Farmers, foresters, landowners, and local residents in most EU member states envisage Natura 2000 as a hindrance to development and often oppose Natura 2000 implementation, according to the gravity of economic interests at stake (Young et al. 2005; Keulartz 2009; Apostolopoulou \& Pantis 2010; Grodzinska-Jurczak \& Cent 2011). In an effort to attenuate the resistance against Natura 2000 and enhance its legitimacy, EU member states have initiated a new open bottom-up participatory governance model for Natura 2000 management. On one hand, this model is widely recognized as the optimal 
governance model that will help Natura 2000 fulfill its goals (Boller et al. 2013; Niedziałkowski et al. 2013). On the other hand, this democratization of Natura 2000 policy making is problematic when it lacks independence and a clear frame of the legal limits to the dialogue process and participants' roles (Buono et al. 2012; Metzner et al. 2013) and when selective actors with vested interests are involved in such a way as to marginalize other important socioenvironmental factors (Ferranti et al. 2013). In this context, the role of scientific experts is often diluted and a divergence from the specific nature conservation goals, inherent to Natura 2000, is apparent (Keulartz 2009; Niedziałkowski et al. 2012).

\section{National and Local Policy}

Respondents identified the lack of political will of national and local governments to fulfill Natura 2000 goals as the main hindrance for successful Natura 2000 implementation. This weakness is aggravated by the lack of efficient national mechanisms for Natura 2000 administration. It seems that political decisions at the European level have failed to be sufficiently adopted by governments at national and local levels, revealing a cross-scale political contradiction and a top-down governance gap (Apostolopoulou et al. 2012; Stringer \& Paavola 2013). Respondents suggested an administration mechanism that closely links EU policy with national, regional, and local authorities.

\section{Heterogeneity of Opinion among Respondents}

Those respondents who had been involved in policy making or in the development of management plans for Natura 2000 sites were the most dissatisfied regarding the implementation of Natura 2000. Policy and management lie at the heart of Natura 2000 implementation complexity, reflecting the challenges conservation scientists envisage in this field and explaining to some extend their dissatisfaction. Respondents who had been employed by NGOs were profoundly critical, given their high appreciation of nature conservation and their advocate role for better Natura 2000 implementation (Evans 2012). Similarly, respondents who had been employed in the governmental sector were critical of Natura 2000 issues, in spite of the more technocratic priorities adopted by governments that often favor development at all costs. In contrast, opinions of academics and nonacademics on Natura 2000 issues did not differ, providing some evidence for the increasing commitment of academics to conservation activities outside their research (Arlettaz et al. 2010). Tree modeling results could help improve Natura 2000 implementation. The need for better EIA was shown to be a crucial point to be considered by EU member states because it was the main suggestion that differentiated less satisfied respondents from the rest. Dissatisfied respondents also tended to stress the need to improve and accelerate infringement procedure in the EU and to focus on conservation action within the Natura 2000 network before considering further conservation action in areas outside the network, as suggested by moderately satisfied respondents.

\section{Natura 2000's Ability to Meet Its Conservation Targets}

Our survey results encapsulated exclusively the opinions of European conservation scientists concerning Natura 2000 , but they can be used to inform further conservation policy decisions in Europe and to guide implementation of other international networks of protected areas. They highlighted $7 \mathrm{key}$ drivers of legal, financial, procedural, scientific, social, and political texture that affect the quality of Natura 2000 implementation. Although respondents deemed there was room for improvement, they esteemed Natura 2000 as a European success at least in terms of network design, adequate integration of external resources, associated European legal frame, and scientific knowledge gain. Respondents pinpointed several Natura 2000 facets meriting substantial improvement, but they stressed in particular the need for better quality control of EIA, especially in view of the negative cumulative effects of small scale or illegal activities. We conclude that EU member states should invest a great effort in the social and policy fields to greatly enhance Natura 2000's ability to meet its nature conservation targets. The main challenges, as identified by survey respondents, are shifting local stakeholder attitudes toward conservation from negative to positive and triggering political action at local and national levels in this direction.

\section{Acknowledgments}

The present study represents an initiative of the Policy Committee of the European Section of the Society for Conservation Biology. The authors are deeply grateful to the survey respondents, to $\mathrm{F}$. Papoulias for providing useful input, and to the members of the Policy Committee of SCB-Europe. We thank O. Nevin for a linguistic revision and 2 anonymous reviewers who provided helpful comments that greatly improved the paper.

\section{Supporting Information}

The questionnaire outline (Appendix S1) and the survey poll (Appendix S2) are available online. The authors are solely responsible for the content and functionality of these materials. Queries (other than absence of the material) should be directed to the corresponding author. 


\section{Literature Cited}

Apostolopoulou, E., E. G. Drakou, and K. Pediaditi. 2012. Participation in the management of Greek Natura 2000 sites: evidence from a cross-level analysis. Journal of Environmental Management 113:308-318.

Apostolopoulou, E., and J. D. Pantis. 2010. Development plans versus conservation: explanation of emergent conflicts and state political handling. Environment and Planning A 42:982-1000.

Araújo, M. B., J. M. Lobo, and J. C. Moreno. 2007. The effectiveness of Iberian protected areas in conserving terrestrial biodiversity. Conservation Biology 21:1423-1432.

Arlettaz, R., M. Schaub, J. Fournier, T. S. Reichlin, A. Sierro, J. E. M. Watson, and V. Braunisch. 2010. From publications to public actions: when conservation biologists bridge the gap between research and implementation. BioScience 60:835-842.

Bastian, O. 2013. The role of biodiversity in supporting ecosystem services in Natura 2000 sites. Ecological Indicators 24:12-22.

BirdLife Europe. 2012. On the road to recovery-Birdlife Assessment of Progress on the EU 2020 Biodiversity Strategy. Belgium.

Boller, F., T. Elscher, M. Erinc, and S. Ulbrich. 2013. Strategies for the implementation of Natura 2000 in cooperation with the organizations involved-the example of the federal States of BadenWürttemberg and Schleswig-Holstein. Naturschutz und Landschaftsplanung 45:322-326.

Bosso, L., H. Rebelo, A. P. Garonna, and D. Russo. 2013. Modelling geographic distribution and detecting conservation gaps in Italy for the threatened beetle Rosalia alpina. Journal for Nature Conservation 21:72-80.

Brodier, S., S. Augiron, T. Cornulier, and V. Bretagnolle. 2013. Local improvement of skylark and corn bunting population trends on intensive arable landscape: a case study of the conservation tool Natura 2000. Animal Conservation 17:204-216.

Buono, F., K. Pediaditi, and G. J. Carsjens. 2012. Local community participation in Italian National Parks Management: theory versus practice. Journal of Environmental Policy and Planning 14:189-208.

Cabeza, M. 2013. Knowledge gaps in protected area effectiveness. Animal Conservation 16:381-382.

Cai, M., and D. Pettenella. 2013. Protecting biodiversity outside protected areas: Can agricultural landscapes contribute to bird conservation on Natura 2000 in Italy? Journal of Environmental Engineering and Landscape Management 21:1-11.

Cent, J., C. Mertens, and K. Niedziałkowski. 2013. Roles and impacts of non-governmental organizations in Natura 2000 implementation in Hungary and Poland. Environmental Conservation 40:119-128.

Chape, S., M. Spalding, and M. D. Jenkins. 2008. The World's protected areas: status, values and prospects in the 21 st century. University of California Press, Berkeley.

Cronbach, L. 1951. Coefficient alpha and the internal structure of tests. Psycometrika 16:297-334.

D'Amen, M., P. Bombi, A. Campanaro, L. Zapponi, M. A. Bologna, and F. Mason. 2013. Protected areas and insect conservation: questioning the effectiveness of natura 2000 network for saproxylic beetles in italy. Animal Conservation 16:370-378.

Dimitrakopoulos, P. G., D. Memtsas, and A. Y. Troumbis. 2004. Questioning the effectiveness of the Natura 2000 special areas of conservation strategy: the case of crete. Global Ecology and Biogeography 13:199-207.

Doak, D. F., V. J. Bakker, B. E. Goldstein, and B. Hale. 2014. What is the future of conservation? Trends in Ecology \& Evolution 29:77-81.

Donald, P. F., F. J. Sanderson, I. J. Burfield, S. M. Bierman, R. D. Gregory, and $\mathrm{Z}$. Waliczky. 2007. International conservation policy delivers benefits for birds in Europe. Science 317:810-813.

Dudley, N., K. J. Mulongoy, S. Cohen, S. Stolton, C. V. Barber, and S. B. Gidda. 2005. Towards effective protected area systems. An action guide to implement the convention on biological diversity programme of work on protected areas. Secretariat of the Convention on Biological Diversity, Montreal.
EC (European Commission). 2004. Financing Natura 2000. EC, Brussels.

EC (European Commission). 2006. Halting the loss of biodiversity by 2010 and beyond. Sustaining ecosystem services for human wellbeing. EC, Brussels.

EC (European Commission). 2011a. Our life insurance, our natural capital: an EU biodiversity strategy to 2020. EC, Brussels.

EC (European Commission). 2011b. Financing Natura 2000. Investing in Natura 2000: delivering benefits for nature and people. EC, Brussels.

EC (European Commission). 2011c. Future EU co-financing of Natura 2000. EC, Brussels.

EC (European Commission). 2013a. The Economic benefits of the Natura 2000 Network. EC, Luxembourg.

EC (European Commission). 2013b. Natura 2000: managing sites in the Natura 2000 network. Nature and Biodiversity Newsletter. EC, Luxembourg.

EEA (European Environmental Agency). 2010a. EU 2010 biodiversity baseline. EEA, Luxembourg.

EEA (European Environmental Agency). 2010b. Public awareness (SEBI 026)-assessment published May 2010. EEA. Available from http://www.eea.europa.eu (accessed May 2010).

EEA (European Environmental Agency). 2011a. Ecological footprint of European countries (SEBI 023) - assessment published May 2010. EEA. Available from http://www.eea.europa.eu (accessed May 2010).

EEA (European Environmental Agency). 2011b. Landscape fragmentation in Europe. Joint EEA-FOEN report. EEA, Luxembourg.

EEA (European Environmental Agency). 2012. Protected areas in Europe-an overview. EEA, Luxembourg.

ETC/BD (European Topic Centre on Biological Diversity). 2008. Online report on article 17 of the Habitats Directive: conservation status of habitats and species of community interest (2001-2006). EC, Paris.

Evans, D. 2012. Building the European Union's Natura 2000 network. Nature Conservation 1:11-26.

Ferranti, F., E. Turnhout, R. Beunen, and J. H. Behagel. 2013. Shifting nature conservation approaches in Natura 2000 and the implications for the roles of stakeholders. Journal of Environmental Planning and Management DOI:10.1080/09640568.2013.827107.

Field, A. 2003. Designing a good questionnaire. Available from http://www.statisticshell.com/docs/designing_questionnaires.

Gaston, K. J., S. F. Jackson, A. Nagy, L. Cantú-Salazar, and M. Johnson. 2008. Protected areas in Europe: principle and practice. Annales of the New York Academy of Science 1134:97-119.

Gillson, L., T. P. Dawson, S. Jack, and M. A. McGeoch. 2013. Accommodating climate change contingencies in conservation strategy. Trends in Ecology \& Evolution 28:135-142.

Grodzinska-Jurczak, M., and J. Cent. 2011. Expansion of nature conservation areas: Problems with natura 2000 implementation in Poland? Environmental Management 47:11-27.

Gruber, B., et al. 2012. "Mind the gap!" - How well does Natura 2000 cover species of European interest? Nature Conservation 3:45-62.

Hamann, A., and S. N. Aitken. 2013. Conservation planning under climate change: accounting for adaptive potential and migration capacity in species distribution models. Diversity and Distributions 19:268-280.

Hovardas, T., and K. Poirazidis. 2006. Evaluation of the environmentalist dimension of ecotourism at the Dadia Forest Reserve (Greece). Environmental Management 38:810-822.

Iojâ, C. I., M. Pâtroescu, L. Rozylowicz, V. D. Popescu, M. Vergheleț, M. I. Zotta, and M. Felciuc. 2010. The efficacy of Romania's protected areas network in conserving biodiversity. Biological Conservation 143:2468-2476.

Jantke, K., C. Schleupner, and U. A. Schneider. 2011. Gap analysis of European wetland species: priority regions for expanding the Natura 2000 network. Biodiversity and Conservation 20:581605 .

Keulartz, J. 2009. European nature conservation and restoration policy-problems and perspectives. Restoration Ecology 17:446450. 
Maiorano, L., A. Falcucci, E. O. Garton, and L. Boitani. 2007. Contribution of the Natura 2000 network to biodiversity conservation in Italy. Conservation Biology 21:1433-1444.

Metzner, J., P. Keller, C. Kretschmar, B. Krettinger, N. Liebig, U. Mäck, and I. Orlich. 2013. Cooperative nature conservation in practiceimplementation examples of landcare groups. Naturschutz und Landschaftsplanung 45:315-321.

Niedziałkowski, K., J. Paavola, and B. Jedrzejewska. 2012. Participation and protected areas governance: the impact of changing influence of local authorities on the conservation of the Białowieża primeval forest, Poland. Ecology and Society 17:2.

Niedziałkowski, K., J. Paavola, and B. Jeçdrzejewska. 2013. Governance of biodiversity in Poland before and after the accession to the EU: the tale of two roads. Environmental Conservation 40:108-118.

Nolte, C., F. Leverington, A. Kettner, M. Marr, G. Nielsen, B. Bomhard, S. Stolton, S. Stoll-Kleemann, and M. Hockings. 2010. Protected area management effectiveness assessments in Europe. A review of application, methods and results. Federal Agency for Nature Conservation (BfN), Bonn, Germany.

Opdam, P. F. M., M. E. A. Broekmeyer, and F. H. Kistenkas. 2009. Identifying uncertainties in judging the significance of human impacts on Natura 2000 sites. Environmental Science and Policy 12:912-921.

Opermanis, O., B. MacSharry, A. Aunins, and Z. Sipkova. 2012. Connectedness and connectivity of the Natura 2000 network of protected areas across country borders in the European Union. Biological Conservation 153:227-238.

Pe'er, G., et al. 2014. EU agricultural reform fails on biodiversity. Science 6188 DOI:10.1126/science.1253425.

Peterson, K., M. Kose, and M. Uustal. 2010. Screening decisions concerning the likely impacts of plans and projects on natura 2000 sites. Journal of Environmental Assessment Policy and Management 12:185-214.
Rego, P. R., M. A. R. Guitián, H. L. Castro, J. F. Da Costa, and C. M. Sobrino. 2013. Loss of european dry heaths in NW Spain: a case study. Diversity 5:557-580.

Schmiedel, I., M. Schmidt, A. Schacherer, and H. Culmsee. 2013. Effectiveness of protection areas for the conservation of rare and endangered vascular plant species-investigation in the lowlands of lower Saxony, Germany. Naturschutz und Landschaftsplanung 45:45-52.

Söderman, T. 2009. Natura 2000 appropriate assessment: shortcomings and improvements in Finnish practice. Environmental Impact Assessment Review 29:79-86.

Stringer, L. C., and J. Paavola. 2013. Participation in environmental conservation and protected area management in Romania: a review of three case studies. Environmental Conservation 40: 138-146.

Tsiafouli, M. A., E. Apostolopoulou, A. D. Mazaris, A. S. Kallimanis, E. G. Drakou, and J. D. Pantis. 2013. Human activities in Natura 2000 sites: a highly diversified conservation network. Environmental Management 51:1025-1033.

Wamelink, G. W. W., B. de Knegt, R. Pouwels, C. Schuiling, R. M. A. Wegman, A. M. Schmidt, H. F. van Dobben, and M. E. Sanders. 2013. Considerable environmental bottlenecks for species listed in the Habitats and Birds Directives in the Netherlands. Biological Conservation 165:43-53.

Wołoszyn, W., W. Kałamucka, M. Kozieł, M. Stanicka, M. Ziółek, and P. Czubla. 2012. Natura 2000 as a platform balancing socioeconomic and environmental objectives-Theory and practice. Annales Universitatis Mariae Curie-Sklodowska. Sectio B 67:263-280.

Young, J., et al. 2005. Towards sustainable land use: identifying and managing the conflicts between human activities and biodiversity conservation in Europe. Biodiversity and Conservation 14:16411661. 